ISMcreatelaw

\title{
Through a Glass, Darkly
}

Creativity vs. the Law

Robert L. Glass

I think everyone agrees that creativity is important in the building of Information Technology (IT) products. But where that agreement really starts to come apart is when we start talking about the role of the law in furthering creativity. Like it or not, the law has a great deal to do with how creativity manifests itself.

What law are we talking about here? The law that is designed to protect intellectual property. Patent law. Copyright law. Trade secret law. Even "work for hire” law.

That law is subject to some of the most fascinating controversies in the world of IT today. Do these intellectual property laws stimulate creativity? Or do they inhibit it?

It is the purpose of this column to explore that issue, but certainly not to resolve it (in fact, it is beyond the power of me the author, you the reader, and in fact the legal system in general, to resolve this particular dispute! The dispute will rage on in the legal and IT worlds long after this issue of this journal has gone out of print and vanished from your shelves and ours).

Here's the gist of the dispute:

On the one side, wearing the red trunks of emphasizing social freedom for the individual, is the Belief that intellectual property law inhibits creativity because it builds walls around new ideas and restricts the ability of innovators to share information about them.

On the other side, wearing the blue trunks of emphasizing profit and business freedom for the individual and/or corporation, is the Belief that intellectual property law enhances creativity because it protects the innovator from copycats and others bent on stealing ideas and profits.

And the key issue distinguishing these two sides is Motivation. Are innovators motivated to do what they do because they love being part of a process of intellectual freedom, standing on the sturdy shoulders of innovators who have gone before them? Or are innovators motivated because they are striving for the achievement of profits, a motivation so strong that they would not choose to do what they do without it? Although some people try to make it so, there's really no right and wrong about this issue. There are just different viewpoints. 
We IT folk tend to think that this dispute is a product of our time, one spawned by the quick rise and spread of IT as a discipline, and as a profit-maker. But that's not at all the case.

The dispute is as old as innovation. In [Wagner 2004], for example, we see that the same dispute was alive and well 120 years ago. Thomas Edison, still today one of the largest patent holders in the U.S., had filed 1093 patents on his various discoveries. Opponents ranged from questioning the validity of the things he patented, to deriding the U.S. Patent Office as "under-qualified” to judge Edison's work. That new-fangled thing called the "light bulb," for example, raised what the article called a "swirl of controversy." Was is really an original discovery, or was Edison relying on the work of others to the extent that his contribution was minimal? Was it significant enough that issuing a patent for it really mattered? Did the Patent Office know enough to pass judgment on these issues?

Patent law, of course, is not the only source of controversy. The arguments for the relevance of copyright and trade secret laws are at least conceptually similar. The Open Source movement, which would tend to come down on the side of wearing the red trunks of social freedom, has invented something it calls the "CopyLeft" agreement that in many ways is the opposite of Copyright because it focuses on the freedoms to distribute its software products, rather than the restrictions to be placed on it. And, of course, when source code is “Open,” all possibilities of trade secret protection fly out the window.

There are, in fact, a history and some identifiable trends to these issues of intellectual property protection. Roland Coles, an attorney, sees the era for trade secret use to be pre1975; for copyright, 1975-1990; and for patents, 1990-the present [Coles 2005]. That explains why so much of our attention more recently has been focused on patents, pro and con.

There is an interesting middle ground to this whole discussion. Software engineering entrepreneur and author Steve McConnell, in philosophical discussions about this topic, sees the dispute as something of a tempest in a teapot. IT and its products change so quickly, he believes, that it is nearly impossible to be sure that some particular approach is new/innovative/protectible and not a revision to something that has been around a long time. ("There are so many different ways to do the same thing," he says, "that the current protection approaches aren't really useful”). An interesting case in point, according to [Wagner 2004], was a suit filed by a company named Eolas Technologies against Microsoft. The suit claimed that Eolas had patented some ways of doing Web page plugins that Microsoft had appropriated for its own products, specifically Internet Explorer. But the Patent Office disagreed, noting that the work that Eolas had patented was based on pre-existing work, having been originated by Tim Berners-Lee a decade or so before. (Note also that the patent office may have made a mistake in accepting that original patent, but its litigation processes allowed it to correct that mistake when it really mattered).

How serious is this dispute? Critics of the current legal system envision "the death of IT innovation.” Others see just the opposite, plenty of innovation happening, pointing to 
huge new industries built around new IT products (linked to the Internet, for example) that didn’t exist until fairly recently.

It's a case of "you pays your money and you makes your choice." Is it really "creativity vs. the law," as our column headline above states (mostly to provoke your curiosity and get you to read this!)? Or is it "creativity plus the law," where the law really stimulates innovation while protecting it? It's your call. And however you call it, no one is going to be able to prove you wrong!

\section{Reference -}

Coles 2005 - Cited in “Open Source Myths and Realities Presented,” the Software Practitioner, May 2005

Wagner 2004 - “For Innovation’s Sake,” InternetNews.com, Nov. 9, 2004; Jim Wagner

"Through a Glass, Darkly,” is a Biblical expression for the unclear way in which we see the world around us.

Robert L. Glass is president of Computing Trends, publishers of The Software Practitioner newsletter, and an Honorary Professor of Software Engineering at Griffith University, Brisbane, Australia. He has been active in the field of computing and software for over 50 years, largely in industry (1954-1982 and 1988-2005), but also as an academic (1982-1988 and 2005-present). He is the author of over 25 books and 95 papers on computing subjects, Editor of The Software Practitioner newsletter, Editor Emeritus of Elsevier's Journal of Systems and Software, and a columnist for several periodicals including IEEE Software's “The Loyal Opposition.” He was a Lecturer for the ACM for 15 years, and was named a Fellow of the ACM in 1998. He received an honorary Ph.D. from Linkoping University in Sweden in 1995. He describes himself by saying "my head is in the academic area of computing, but my heart is in its practice." 